Nama : felisitas gloria hendrika kaka

Nim : 2161B0024

Prodi : s1 farmasi

Email : felisitasgloriahendrikak@gmail.com

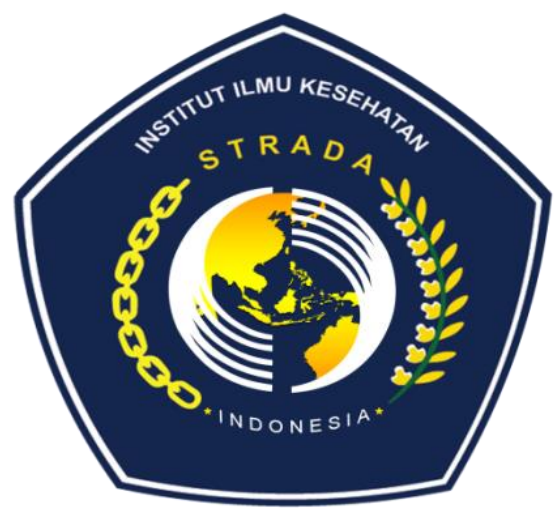

\title{
KONSEPSI DAN IMPLEMENTASI DEMOKRASI PANCASILA DALAM SISTEM PERPOLITIKAN DI INDOENSIA
}

\section{Agustam*}

\begin{abstract}
Abstrak
Demokrasi Barat yang dilahirkan oleh Revolusi Prancis tiada membawa kemerdekaan rakyat yang sebenarnya, melainkan menimbulkan kekuasaan kapitalisme, sebab itu demokrasi politik saja tidaklah cukup untuk mencapai demokrasi yang sebenarnya yaitu kedaulatan rakyat. Haruslah ada pula kedaulatan ekonomi, yang memakai dasar, bahwa segala penghasilan yang mengenal penghidupan orang banyak harus berlaku dibawah tanggungan orang banyak juga. Mengapa demokrasi selalu menjadi tema dan pilihan moral dalam perjuangan politik? Karena manusia menyadari dirinya memiliki kelemahan moral berupa kecenderungan untuk berkuasa dan menguasai orang lain. Jika kecenderungan ini melekat pada seseorang yang kebetulan tengah menggenggam kekuasaan dan disitu tidak ada mekanisme kontrol yang bisa memperingatkan dan mengendalikannya, maka biasanya rakyat yang akan menjadi korban.
\end{abstract}


Kata Kunci : Konsepsi, Implementasi, Demokrasi, Politik Indonesia

\section{Pendahuluan}

Model demokasi Barat yang berkembang dewasa ini dan banyak dipuji orang, bukanlah suatu prestasi politik yang datang tibatiba. Kondisi itu merupakan resultan dari proses sejarah yang teramat panjang. Untuk sampai pada pelembagaan etika politik yang lebih beradab itu saja, sudah jutaan jiwa manusia yang menjadi ongkosnya. Begitu pula dengan kemerdekaan bangsa Indonesia yang tidak diperoleh secara gratis, melainkan harus dijemput dengan perjuangan untuk survive dan bangkit melawan imprialisme Barat yang mengaku sebagai bangsa yang beradab itu.

Pengalaman bangsa Indonesia relatif masih miskin dalam mewujudkan sistem demokrasi yang merupakan ciri utama masyarakat Indonesia. Ibarat lahan perkebunan, wacana dan ladang perpolitkan di Indonesia sampai saat ini masih dalam proses simbiose kimiawi antara bibit demokrasi liberal yang di impor dari Barat dengan lahan kultural Indonesia yang dahulunya subur bagi pohon feodalisme. Berbeda dari tanaman nabati yang bersifat obyektif dan tumbuh linear mengikuti kaidah alam, dunia politik adalah dunia intersubyektif yang menyimpan berbagai kemungkinan yang sulit diramalkan, karena subyek dan obyeknya sama-sama manusia yng masing-masing memiliki ambisi, kehendak dan kebebasan. Dalam suat masyarakat yang sistem dan kultur demokrasinya telah mapan, tidaklah sulit membaca perkembangan dan arah politik yang hendak dituju dari pemilu ke pemilu, karena setiap partai yang berkuasa akan terikat oleh janji, program dan mekanisme kerja yang ditawarkan kepada rakyat selama kampanye. Tetapi bagi Negara-negara yang masih berkembang seperti Indonesia yang sebelumnya hidup dibawah kekuasaan raja ataupun penjajah selama ratusan tahun, mental dan lahan kulturalnya lebih kondusif bagi lahirnya kepemimpinan yang berpusat pada figur personal, bukannya sebuah sistem politik nasional yang bersifat impersonal. Dalam kontek Indonesia, tentu saja sejak awal kelahirannya para pemimpin bangsa telah berusaha meletakkan dasar-dasar birokrasi kenegaraan modern. Hanya saja, Ibarat benih pohon tadi, ketika institusi formal tidak memperoleh dukungan lahan kultural yang gembur dan cocok, maka kita harus bekerja keras untuk menghancurkan bebatuan dan cadas yang ada, agar akar bibit demokrasi bisa meresap dan tertanam kukuh, yang pada gilirannya bisa menyangga pohon demokrasi dengan daun dan buahnya yang rindang, tempat rakyat bernaung

Secara faktual, gagasan tentang demokrasi bermula dari negara-negara Barat, khususnya Inggris, Amerika dan Prancis. Akar ideologi demokrasi Barat adalah Liberalisme, Menurut Ali Mudhafir (2008:47) Liberalisme merupakan aliran Filsafat yang mempertahankan kebebasan perseorangan terhadap kekuasaan yang hendak berlaku secara mutlak. Kebebasan ini mencakup bidang agama,ekonomi dan politik. Liberalisme kemudian menjadi moralitas tertinggi bagi kemajuan bersama, yaitu kebebasan individu dalam kehidupan bernegara. Yang kemudian melahirkan nasionalisme dan demokrasi dalam kehidupan politik, melahirkan tatanan kapitalis dengan semboyan Laisser Faire, laisser passer le monde va de luimeme 
(produksi bebas, perdagangan bebas, hukum kodrat akan menyelenggarakan harmaoni dunia) dibidang ekonomi, dan kebebasan beragama dengn sekularisme. Terhadap pemahaman demokrasi Barat ini, Hatta (2010:14) mengatakan bahwa kebebasan individu ini nantinya mengakibatkan ketidakadilan dalam masyarakat, karena kedaulatan hanya berpusat pada para pemilik modal, kritik selajutnya dapat kita abaca sebagai berikut : "Jadinya, demokrasi Barat yang dilahirkan oleh Revolusi Prancis tiada membawa kemerdekaan rakyat yang sebenarnya, melainkan menimbulkan kekuasaan kapitalisme, sebab itu demokrasi politik saja tidaklah cukup untuk mencapai demokrasi yang sebenarnya yaitu kedaulatan rakyat. Haruslah ada pula kedaulatan ekonomi, yang memakai dasar, bahwa segala penghasilan yang mengenal penghidupan orang banyak harus berlaku dibawah tanggungan orang banyak juga."1 Dari kutipan diatas dapat disimpulkan bahwa demokrasi Barat hanya memberikan kedaulatan kaum pemodal, Hatta menambahkan, demokrasikapitalis inilah yang harus ditolak dan tidak cocok untuk Indonesia. Sebaliknya, demokrasi modern yang berbasis pada nasionalisme religius adalah bentuk demokrasi yang dicita-citakan bangsa Indonesia yang Kemudian merupakan cikal bakal lahirnya Demokrasi Pancasila. Berdasarkan latar belakang tersebut diatas, maka yang menjadi rumusan masalah mengenai konsepsi dan paktek demokrasi Pancasila adalah :Bagaimanakah Konsep dan Praktek Demokrasi Pancasila diterapkan di Indonesia. Pengertian Demokrasi Pancasila Secara ringkas, demokrasi Pancasila memiliki beberapa pengertian sebagai berikut:

1. Demokrasi Pancasila adalah demokrasi yang berdasarkan kekeluargaan dan gotongroyong yang ditujukan kepada kesejahteraan rakyat, yang mengandung unsur-unsur berkesadaran religius, berdasarkan kebenaran, kecintaan dan budi pekerti luhur, berkepribadian Indonesia dan berkesinambungan.

2. Dalam demokrasi Pancasila, sistem pengorganisasian negara dilakukan oleh rakyat sendiri atau dengan persetujuan rakyat.

3. Dalam demokrasi Pancasila kebebasan individu tidak bersifat mutlak, tetapi harus diselaraskan dengan tanggung jawab sosial.

4. Dalam demokrasi Pancasila, keuniversalan cita-cita demokrasi dipadukan dengan cita-cita hidup bangsa Indonesia yang dijiwai oleh semangat kekeluargaan, sehingga tidak ada dominasi mayoritas atau minoritas

Dalam Rancangan TAP MPR RI tentang Demokrasi Pancasila disebutkan bahwa Demokrasi Pancasila adalah norma yang mengatur penyelenggaraan kedaulatan rakyat dan penyelenggaraan pemerintahan negara, dalam kehidupan politik, ekonomi, sosial budaya, dan pertahanan keamanan, bagi setiap warga negara Republik Indonesia, organisasi kekuatan sosial politik, organisasi kemasyarakatan, dan lembaga kemasyarakatan lainnya serta lembagalembaga negara baik di pusat maupun di daerah.

- Prinsip-prinsip Demokasi Pancasila Prinsip-prinsip demokrasi: 
1) Kebebasan atau persamaan (Freedom/Equality) Kebebasan / persamaan adalah dasar demokrasi.Kebebasan dianggap sebagai sarana mencapai kemajuan dan memberikan hasil maksimal dari usaha orang tanpa pembatasan dari penguasa.Dengan prinsip persamaan semua orang dianggap sama,tanpa dibeda-bedakan dan memperoleh akses dan kesempatan bersama untuk mengembangkan diri sesuai dengan potensinya. Kebebasan yang dikandung dalam demokrasi Pancasila ini tidak berarti Free Fight Liberalism yang tumbuh di Barat, tapi kebebasan yang tidak mengganggu hak dan kebebasan orang lain.

2) Kedaulatan Rakyat (people's Sovereignty).

Dengan konsep kedaulatan rakyat,hakikat kebijakan yang dibuat adalah kehendak rakyat dan untuk kepentingan rakyat.Mekanisme semacam ini akan mencapai dua hal.Pertama.kecil kemungkinan terjadinya penyalah gunaan kekuasaan,sedangkan kedua,terjaminnya

kepentingan rakyat dalam tugas-tugas pemerintahan.Perwujudan lain konsep kedaulatan adalah pengawas oleh rakyat.Pengawasan dilakukan karena demokrasi tidak mempercayai kebaikan hati penguasa.

3) Pemerintahan yang terbuka dan bertanggung jawab

a) Dewan Perwakilan Rakyat yang representatip.

b) Badan kehakiman / peradilan yang bebas dan merdeka.1 198-

c) Pers yang bebas

d) Prinsip Negara hukum

e) Sistem dwi partai atau multi partai.

f) Pemilihan umum yang demokratis

g) Prinsip mayoritas.

h) Jaminan akan hak-hak dasar dan hak-hak minoritas

Dinegara kita, prinsip-prinsip demokrasi telah disusun sesuai dengan nilai-nilai yang tumbuh dalam masyarakat, meski harus dikatakan baru sebatas demokrasi prosedural, dalam proses pengambilan keputusan lebih mengedepan voting ketimbang musyawarah untuk mufakat, yang sejatinya merupakan azas asli demokrasi Indonesia. Praktek demokrasi ini tanpa dilandasi mental state yang berakar dari nilai-nilai luhur bangsa merupakan gerakan omong kosong belaka.

Unsur-Unsur Demokrasi. Beberapa Unsur demokrasi yang dikemukakan oleh para Ahli adalah sebagai berikut:

1) Menurut Sargen,Lyman Tower(1987),yaitu keterlibatan rakyat dalam mengambil keputusan politik,tingkat persamaan hak antarmanusia,tingkat kebebasan dan kemerdekaan yang di miliki oleh warga Negara,system perwakilan dan system pemilihan ketentuan manyoritas.

2) Munurut AfanGaffar(1999), Yaitu akuntabilitas,rotasi kekuasaan,rekruitmen politik yang terbuka,pemilihan umum,dan hak-hak dasar. 
3) Menurut Merriam Budiardjo(1977),perlunya dibentuk lembaga-lembaga demoktasi untuk melaksanakan nilai-nilai demoktasi,yaitu pemerintahan yang bertanggung jawab,Dewa Perwakilan Rakyat,organisasi politik,pers dan media massa,serta peradilan yang bebas.

4) Menurut Frans Magnis Suseno(1997).menyebutkan ada lima gugus ciri hakiki Negara demokrasi.Kelima gugus demokrasi tersebut adalh Negara hokum,pemerintahan dibawah control nyata masyarakat,pemilihan umum yang bebas,prinsip manyoritas dan adanya jaminan terhadap hak-hak demokrasi.

\section{Pelaksanaan Demokrasi Pancasila di Indonesia}

Konsep demokrasi pancasila digali dari nilai masyarakat asli Indonesia dengan nilainilai yang melekat kepadanya, seperti desa demokrasi, rapat kolektivisme, musyawarah, mupakat, tolongmenolong dan istilah-istilah lain yang berkaitan dengan itu. Tujuannya, memberikan pendasaran emperis sosiologis tentang konsep demokrasi yang sesuai dengan sifat kehidupan masyarakat asli Indonesia, bukan sesuatu yang asing yang bersal dari barat dan dipaksakan pada realitas kehidupan bangsa Indonesia. Masyarakat asli yang dimaksudkan disini adalah bentuk kehidupan masyarakat yang sudah berlangsung dipulau-pulau di nusantara sejak berabad-abad yang lalu dan yang tersusun dari satuan-satuan kehidupan yang terkecil yang berbeda-beda seperti desa di jawa, nagari di Sumatra barat, pekon dilampung atau subak di bali. Masyarakat asli ini memiliki seperangkat nilai mental dan moral yang bersifat homogen, struktural dan kolektif, yang kesemuanya memiliki sistem budaya sendiri dan berlangsung secara demokratis, yaitu demokrasi secara langsung sebagaimana terdapat dinegara-negara kota di yunani kuno 25 abad yang lalu. Proses metamorphosis niali-nilai

demokrasi yang digali dari kearifan budaya Indonesia tersebut mengalami beberapa prioderisasi dalam proses implementasinya sebagai suatu keniscayaan, dan tahapan tersebut 
dapat dilihat dalam uraian berikut ini. Pelaksanaan demokrasi di Indonesia dapat dibagi ke dalam lima priode :

1. Pelaksanaan demokrasi masa revolusi 1945-1950.

2. Pelaksanaan demokrasi masa orde lama.

a. Masa demokrasi liberal 1950-1959.

b. Masa demokrasi terpimpim tahun 1959-1965.

3. Pealaksanaan demokrasi masa orde baru tahun 1966-1998.

4. Pelaksanaan demokrasi masa transisi tahun 1998-1999.

5. Pelaksanaan demokrasi masa reformasi tahun 1999 sampai sekarang.

Pelaksanaan Demokrasi Masa Revolusi Tahun 1945-1950 Indonesia masih berjuang mengghadapi belanda yang ingin kembali ke Indonesia.Pada masa itu penyelenggaraan pemerintah dan demokrasi Indonesia belum berjalan baik.Hal itu disebabkan masih adanya revolusi fisik.Berdasarkan pada konstitusi Negara, yaitu UUD 1945, Indonesia adalah Negara demokrasi yang berkedaulatan rakyat.Masa pemerintahan tahun 1945- 1950 mengindikasikan keinginan kuat dari para pemimpin Negara untuk membentuk pemerintahan demokratis. Untuk menghindari kesan bahwa Negara Indonesia adalah Negara absolute maka dilakukan serangkaiaan Kebijakan untuk menciptakan pemerintahan demokratis. Kebijakan tersebut adalah sebagai berikut

a) Maklumat pemerintah No. X tanggal 16 oktober 1945 tentang perubahan fungsi KNIP menjadi Fungsi parlemen.

b) Maklumat pemerintah tanggal 3 November 1945 Mengenai pembentukan partai politik.

c) Maklumat pemerintah tanggal 14 N0vember 1945 mengenai perubahan cabinet ke cabinet parlementer.

Dengan kebijakan tersebut terjadi perubahan dalam sistem pemerintahan di Indonesia.Sistem pemerintahan berubah menjadi system pemerintahan parlementer.Cita-cita dan proses demokrasi masa itu trhambat oleh revolusi fisik menghadapi belanda dan pemberontakan PKI madiun tahun 1948

1. Pelaksanaan Demokrasi masa Orde Lama

Masa Demokrasi Liberal Proses demokrasi pada masa itu telah dinilai gagal dalam menjamin stabilitas politik,kelangsungan pemerintahan,dan penciptaan kesejahteraan rakyat.Kegagalan pratik demokrasi parlementer atau liberal tersebut disebabkan oleh beberapa hal,yaitu sebagai berikut:

a) Dominannya politik aliran.

b) Landasan sosial ekonomi rakyat yang masih rendah.

c) Tidak mempunyai para anggota konstituante dalam bersidang menetapkan dasar Negara sehingga keadaan menjadi berlarutlarut.Hal ini menjadikan presiden soekarno mengeluarkan Dekrit Presidan tanggal 5 juli 1959.

Dengan turunnya dekrit presiden tersebut,berakhirlah masa demokrasi parlementer atau demokrasi liberal di Indonesia.selanjutnya Indonesia memasuki masa demokrasi terpimpin 


\section{Masa Demokrasi Terpimpin.}

Masa antar tahun 1959-1965 adalah periode demokrasi terpimpin.Pengertian dasar demokrasi terpimpin menurut ketetapan MPR S No. VIII/MPRS/1965 adalah kerakyatan yang dipimpin oleh hikmah kebijaksanaan dalam permusyawaratan / perwakilan yang berintikan musyawarah untuk mufakat secara gotong royong diantara semua kekuatan nasional yang progresif revulusioner dengan berporoskan nasakom.

Adapun ciri-ciri demokrasi terpimpin adalah sebagai berikut:

a) Dominasi presiden, artinya Presiden Soekarno sangat berperan dalam menentukan penyelenggaraan pemerintahan Negara.

b) Terbatasnya peran partai politik.

c) Berkembangnya pengaruh PKI dan militer sebagai kekuatan sosial politik di Indonesia.

\section{Pelaksanaan Demokrasi Masa Orde Baru.}

Masa Orde baru dimulai tahun 1966.Demokrasi masa orde baru bercirikan pada kuatnya kekuasaan presiden dalam menopang dan mengatur seluruh proses politik yang terjadi.Lembaga kepresidenan telah menjadi pusat dari seluruh proses politik dan menjadi pembentuk dan penentu agenda nasional,mengontrol kegiatan politik dan pemberi legalitas bagi seluruh anggota pemerintah dan Negara.Akibatnya,secara substantive tidak ada perkembangan demokrasi dan justru penurunan derajat demokrasi. Orde baru sesungguhnya telah mampu membangun stabiliats pemerintahan dan kemajuain ekonomi.Namun,makin lama semakin jauh dari semangat demokrasi dan kontrol rakyat. Pemerintahan orde baru berakhir pada saat Presiden Soeharto mengumumkan pengunduran dirinya dari kekuasaannya pada tanggal 29 Mei 1998. Berakhirnya orde baru membuka jalan munculnya Masa Transisi dan periode Reformasi.

\section{Pelaksanaan Demokrasi Masa Transisi.}

Masa transisi berlangsung antara 1998-1999.Pada masa transisi banyak sekali pembangunandan perkembangan kearah kehidupan Negara demoktasi.Beberapa pembangunan kearah demokrasi tersebut adalah sebagai berikut:

a) Keluarnya ketetapan MPR RI Dalam siding istimewa bulan November 1998 sebagai awal perubahan sitem demokrasi secara konstitusional.

b) Adanya jaminan kebebasan pendirian partai poltik ataupun organisasi kemasyarakatan secara luas.

c) Melaksanakan pemilihan umum 1999 yang bebas dan demokratis dengan diikuti banyak partai politik.

d) Terbukanya kesempatan yang luas dan untuk warga Negara dalam melaksanakan demokrasi di berbagai bidang.Demokrasi saat itu menjadi harapan banyak orang sehingga sering eufhoria demokrasi.

\section{Pelaksanaan Demokrasi Masa Reformasi.}

Di masa Reformasi ini juga terdapat peningkatan prinsipprinsip demokrasi yang terpenting,yaitu jaminan penegakan hak asasi manusia dengan di keluarkannya UndangUndang No. 39 Tahun 1999 tentang HAM dan Undang-Undang No. 26 Tahun 2000 tentang 
Pengadilan Hak asasi manusia. Pelaksanaan demokrasi yang sangat penting pada masa reformasi ini adalah adanya amandemen terhadap UUD 1945.,Amandemen UUD 1945 dimaksudkan untuk mengubah dan memperbaharui konstitusi Negara agar sesuai dengan prinsip-prinsip Negara demokrasi.Proses amandemen terhadap UUD 1945 adalah

a). Amandemen pertama tahun 1999

b). Amandemen kedua tahun 2000

c). Amandemen ketiga tahun 2001.

d). Amandemen keempat tahun 2002

Kesimpulan

1) Konsep demokrasi pancasila tidak bersumber dari paham individualisme yang berkembang di barat meski tak bisa di tampik nilai-nilai liberal yang membentuk demokrasi dibarat seperti kesetaraan hak warga Negara, kebebasan berpendapat sebagai pilar demokrasi yang utama, berpengaruh kuat terhadap pengayaan demokrasi pancasila. Demokrasi pancasila yang dimunculkan adalah demokrasi berdasarkan paham kebersamaan dan kekeluargaan, substansi dari demokrasi model ini adalah sikap kritis terhadap kebijakan penguasa, musyawarah untuk mencapai mupakat dalam pengambilan keputusan politik dan kebiasaan tolong menolong atau gotong royong.

2) Praktek demokrasi pancasila di Indonesia itu bercorak pada nasionalisme religius bukan kepada nasionalis sekuler. Hal ini dapat kita lihat pada sila pertama Pancasila yang mengakomadasi nilai-nilai ketuhanan dalam ideologi Negara sebagai landasan dasar berbangsa dan bernegara.

\section{DAFTAR PUSTAKA}

Siyoto,S., \& Sodik, Ma (2015). Dasar Metodologi Penelitian . Penerbit Media Literasi

Adian Donny Grahral, Demokrasi Substansial,Jakarta: Koekoesan, Jakarta,2010. Hidayat, Komaruddin, Tragedi Raja Midas, Jakarta: Paramadina,2008. Asshiddiqie, Jimly, Hukum Tatanegara dan Pilar-pilar Demokrasi, Jakarta: Sinar Grafika,2011.

Suleman, Zulfikri, Demokrasi Untuk Indonesia, Jakarta: Kompas,2010. Nasution, Adnan Buyung. 2010. Demokrasi Konstitusional.Jakarta: Kompas,2010. Mudhofir, Ali, Kamus Teori dan Aliran Dalam Filsafat, Jakarta: Liberti,2008. Latif, Yudi, Negara Paripurna (historis, rasionalitas, dan aktualitas pancasila). Jakarta: Kompas Gramedia,2011. 